\title{
Antalya Büyükşehir Belediyesinin Mali Yapısının Değerlendirilmesi*
}

\author{
Evaluation of Antalya Metropolitan Municipality in Terms pf Financial Structure
}

\section{Şerife AYGÜN KOZA}

Bilim Uzmanl, serifeaygun@sdu.edu.tr

https://orcid.org/0000-0002-4949-9514
Makale Başvuru Tarihi / Received: 23.01.2019

Makale Kabul Tarihi / Accepted: 23.04.2019

Makale Türü / Article Type: Araştırma Makalesi

\author{
Ceyda ŞATAF \\ Dr. Ögr. Üyesi, Süleyman Demirel Üniversitesi, \\ IIBF, Maliye Bölümü, ceydasataf@sdu.edu.tr \\ https://orcid.org/0000-0002-7112-6546
}

\section{ÖZET}

$\begin{aligned} & \text { Anahtar } \\ & \text { Kelimeler: }\end{aligned}$
Mali Yapı,
Büyükşehir
Belediyesi,
Antalya
Büyükşehir
Belediyesi,

Keywords:

Financial Structure,

Metropolitan

Municipalities,

Antalya

Metropolitan

Municipalities,

\begin{abstract}
Ülkemizde ve dünyada kamu hizmetlerinin sunumu açısından yerel yönetimlerin rolü ve önemi giderek artmaktadır. Yerel hizmetlerin arzında önemli bir yere sahip olan yerel yönetim birimi de belediyelerdir. Ekonomik, siyasal ve sosyal yönlü gelişmelerle birlikte nüfus yapısındaki hareketlenme ve nüfus artışı şehirlerin büyümesine neden olmuştur. Büyüyen ve genişleyen şehirlerde yönetim kolaylı̆̆ açısından bazı girişimlerde bulunulmuş ve sonucunda büyükşehir belediyeleri kurulmuştur. Büyükşsehir belediyelerinin halkın ihtiyacı olan hizmetleri etkin bir şekilde yerine getirebilmeleri amacıyla mali açıdan (gelir-harcamaborçlanma gibi) güçlü bir mali yapıya sahip olmaları gerekmektedir. Büyükşehir belediyeleri, Türkiye'nin mali yapısı açısından önemli bir yere sahiptir. Bu nedenle, geçmişten günümüze gelen kanun değişiklikleriyle yerel yönetimlerin payları değiştirilerek belediyelerin ve büyü̈şehir belediyelerinin mali açıdan güçlendirilmesi sağlanmaya çalışılmıştır. Bu bağlamda bu çalışmada, büyükşshir belediyelerinin mali yapısını Antalya Büyükşehir Belediyesi örneği üzerinden incelemektir. Çalışmada, genel olarak büyükşehir belediyelerinin kanunları çerçevesinde mali yapılarında ne gibi değişikliklerin olduğu ve bu değişikliklerin Antalya Büyükşsehir Belediyesi üzerindeki etkilerini incelemek amaçlanmaktadır. Bu kapsamda, Antalya Büyükşehir Belediyesi'nin 2006-2017 yıllarını kapsayan döneminde mali yapı açısından gelir-gider karşılaştırmaları, bütçede en fazla paya sahip olan kalemlerin nedenleri ve oluşan finansman açılarının nasıl karşılandiğı analiz edilmiştir. Sonuç olarak, Antalya Büyükşsehir Belediyesinin mali yapısı incelendiğinde tahmin edilen bütçeden çok fazla sapma olmadı̆̆ ve gereksiz borçlanmaya başvurmadıkları görülmüştür.
\end{abstract}

\begin{abstract}
The purpose of this study is to examine, the financial structure of Antalya Metropolitan Municipality. The role and importance of local governments in the presentation of government policy in our country and in the world is gradually increasing. The local government unit, which has an important place in the provision of local services, is the municipalities. Together with the economic, political and social developments, movements of population structure and population growth have led to the growth of cities. In the growing and expanding cities, some attempts have been made in terms of ease of management and as a result metropolitan municipalities have been established. Municipalities and metropolitan municipalities need to have a strong financial structure (such as income-expenses-borrowing) so that the public can perform their services effectively. Metropolitan municipalities have an important place in Turkey's financial terms. For this reason, with the amendments from the past to the present, the shares of the local administrations have been changed and the financial strengthening of the municipalities and metropolitan municipalities has been tried to be provided. The purpose of this study is to examine the changes in the financial structure of the metropolitan municipalities and the effects of these changes on the Antalya Metropolitan Municipality. The income and expenditure comparisons of the financial structure of Antalya Metropolitan Municipality in the period 2006 2017, the reasons for the items with the highest share in the budget and how the financing deficits were supplied and analyzed. As a result, when the financial structure of Antalya Metropolitan Municipality is examined, it is seen that there is not much deviation from the estimated budget and they do not resort to unnecessary borrowing.
\end{abstract}

* Bu çalışma Dr.Öğr.Üyesi Ceyda ŞATAF danışmanlığında hazırlanan ve Süleyman Demirel Üniversitesi Bilimsel Araştırma Projeleri Koordinasyon Birimi tarafindan desteklenen 4787 YL1-16 No'lu Yüksek Lisans Tez projesinden oluşturulmuştur. 


\section{GIRISS}

Türkiye'de mahalli idare birimleri, 1982 Anayasası'nda il özel idareleri, belediyeler ve köyler olmak üzere üç kademeli olarak şekillendirilmiştir. 1982 Anayasası'nın 127'inci maddesinde büyük yerleşim merkezlerinin farklılık gösteren hizmetlerini daha etkin bir şekilde yapabilmek için, ilgili bölgelerde özel yönetim birimleri kurulabileceği belirtilmiştir. Bu temelde, 1984 yılında 3030 sayılı Büyükşehir Belediyesi Yasası yürürlüğe girmiş ve ilk büyükşehir belediyeleri oluşturulmuştur. Dünyada yaşanan küreselleşme olgusu toplumsal ihtiyaçları değiş̧tirmiş, ihtiyaçlardaki bu değişiklikler ülkeleri etkilemiştir. Ülkelerdeki yönetimde bulunan hükümetler yasa değişiklikleri ve yeni kanunlar yaparak bu ihtiyaçları gidermeye çalışmıştır. Türkiye'de bu yeni ihtiyaçlara uygun olarak yeni kanunlar çıkarmıştır. 1984 yılında kabul edilen ilk büyükşehir belediye kanunu 3030 sayılı Kanun'dur. Bu ihtiyaçlara uygun olarak 3030 sayılı Büyükşehir Belediye Kanunu kaldırılarak, bu kanun yerine 10.07.2004 yılında kabul edilen 5216 sayılı "Büyükşehir Belediyesi Kanunu" getirilmiştir. 2004 yılındaki 5216 sayılı Büyükşehir Belediye Yasası ölçek ve nüfus kriteri açısından yenilikler getirmiştir. Türkiye'de büyükşehir belediye sisteminin yeniden şekillenmesini sağlayan 6360 sayılı "On Dört İlde Büyükşehir Belediyesi ve Yirmi Yedi İlçe Kurulması İle Bazı Kanun ve Kanun Hükmünde Kararnamelerde Değişiklik Yapılmasına Dair Kanun" 12.11.2012 tarihinde kabul edilmiştir. Ancak kanun 30 Mart 2014 tarihli mahalli idare seçimleri sonrasında yürürlüğe girerek uygulanmaya başlanmıştır. 2014 yılında toplam büyükşehir belediyesi sayısı 30'a ulaşmıştır.

Büyükşehir belediyelerinin yerel nitelikteki kamu hizmetlerini etkin, ekonomik ve verimli bir şekilde sunabilmesi için görevleri ile orantılı, verimli ve istikrarlı gelir kaynaklarına sahip olması gerekmektedir. Diğer bir deyişle büyükşehir belediyelerinde giderek artan ve çeşitlenen yerel ihtiyaçlar ve bekelentiler güçlü bir mali yapıya sahip olunmasını gerektirmektedir.

Çalışma üç bölümden oluşmaktadır. Çalışmanın birinci bölümünde, Türkiye'deki büyükşehir sistemine geçiş süreci kanunlar bazında incelenmektedir. Büyükşehir belediyelerinin mali yapısı başlıklı ikinci bölümde; büyükşehir belediyelerinin gelirleri, giderleri, bütçe denkliği incelenmektedir. Son bölümde, Antalya Büyükşsehir Belediyesine ait stratejik planlar, performans programları ve faaliyet raporları üzerinden mali yapısı incelenmektedir.

\section{TÜRKIYYE'DE BÜYÜKŞEHIIR YÖNETIMININ OLUŞUM SÜRECI}

Türkiye'de 1950'li yıllarda kentlerin nüfusları hızla artmaya başlamıştır. Bu hızlı nüfus artışına paralel oalrak 1930 tarihli ve 1580 sayılı Belediye Kanunu'nun yetersiz ve eksik kalmıştır. 1960-1980 yılları arasında Bakanlar Kurulu tarafından İstanbul, İzmir ve Ankara illerinde imar planlama büroları kurulmuş ve büroların sayıs1 10'a ulaşmıştır. Söz konusu dönemler içerisinde ana kentlerin yönetilmesi konusunda yasal düzenlemeler yapılmaya çalışılmış ama yürürlüğe girmemiştir. (Özçelik, 2014:1121-1122).

1960’11 yıllardan sonra büyükşehir hizmet birlikleri ve yönetim yapısı oluşturmak için çalışmalar başlatılmıştır. Bu nedenle 1980 öncesindeki büyükşsehir çalışmalarının 1960 ve 1984 arasında yoğunluk kazandığı söylenebilir. Büyükşehir belediyelerini ortaya çıkaran nedenlere bakıldığında, 1980'li yıllarda tüm dünyadaki büyük yerleşim alanları için farklı bir yönetim sistemi arayışı içine girilmesinin önemli bir etken olduğu göze çarpmaktadır. Çoğu yerde gerçekten de merkeziyetçi yaklaşımların yerel hizmetlerin sunulmasında büyük tıkanıklara yol açtığ görülmüştür. Bu darboğazın aşılması için belde halkının yönetime daha geniş ve etkin bir şekilde katılmasının sağlanması, hizmet sunumunda etkinliğin ve verimliliğin arttırılmasına katkıda bulunmuştur (Öner, 2006:249).

Büyükşehir belediyesi modelinde temel nokta yerel hizmetlerin sunumu için federatif bir yapıdaki anlayışa benzer şekilde alt basamakta (ilçe belediyesi) sunulamayan veya sunulmasında sorun oluşacak durumlarda metropol alan hizmetlerini (büyükşehir belediyesi) yerine getirme düşüncesidir (Azaklı ve Özgür, 2005:315).

Büyükşehir belediyeleri ile ilgili ilk kanun (3030 sayılı Büyükşehir Belediyesi Kanunu) Türkiye Cumhuriyeti kurulduktan 61 y1l sonra (1984 tarihinde) yürürlüğe girerek Türk belediye sisteminde yerini almıştır. 3030 sayılı Kanun, büyükşehir belediyeleri deneyiminde ilk olması ve 2004 yılına kadar yürürlükte kalması nedenleriyle değerlendirilmesi gereken önemli bir kanundur. Söz konusu kanunun içeriğinde "büyükşehir" kavramı ilk kez açıklanmıştır. Türkiye'de ilk defa 3030 sayılı kanunla hayata geçirilen büyükşehir belediye sisteminde görev ve yetkilerin paylaşılması konusunda herhangi bir ölçütün bulunmaması, yönetim kademeleri arasında işbirliği kurulmaması, büyükşehir belediyelerinin ilçe ve alt kademe belediyeleri üzerinde bir egemenliğin bulunmaması, 
büyükşehir kapsamında bir planlama ve koordinasyonun yapılamaması ve belediye büyüklüklerinin farklı olması gibi nedenler uygulama aşamasında bazı eksikliklere ve sorunlara sebep olmuştur. Bu da hizmetleri olumsuz etkilemiş, kaynakların etkinsiz kullanılmasına neden olmuştur (Ulusoy ve Akdemir, 2014:264).

3030 sayılı kanun hakkındaki tüm bu eleştirilere rağmen 20 yıl boyunca uygulanmıştır. TBMM'de 10 Temmuz 2004 tarihinde kabul edilen ve 23 Temmuz 2004 tarihinde yürürlüğe giren 5216 sayılı Büyükşehir Belediyesi Kanunu ile 3030 sayılı Büyükşehir Belediyesi Kanunu yürürlükten kaldırılmıştır (Öner, 2006:260).

Büyükşsehir belediyesi yönetim sistemimizde çok önemli değişiklikler içeren ve 14 ilin büyükşehir olmasını öngören ve yerel yönetim sistemimize yeni uygulamalar getiren 6360 say1l1, "14 ilde Büyükşehir Belediyesi Kanunu ile Bazı Kanun ve Kanun Hükmünde Kararnamelerde Değişiklik Yapılmasına Dair Kanun” TBMM'de kabul edilmiştir. 6360 sayılı Yeni Büyükşehir Kanunu olarak yeni düzenleme Cumhurbaşkanı tarafindan onaylanarak bazı maddeleri yayın tarihi itibariyle yürürlüğe girmiş, bazı maddeleri de 2014 Mart'ta ki Mahalli İdare seçimlerini takiben yürürlüğe girmiştir. Bu kanun ülkemizde yerel yönetim ve il yönetimi alanında önemli değişiklikler getirmiştir (Parlak, 2015:129).

\section{BÜYÜKŞEHİR BELEDIYYLLERINIIN MALİ YAPISI}

Yerel yönetimler merkezi otoritenin (yasama) kabulü olmadan kendi başlarına vergi ve benzeri gelir koyamazlar ve toplayamazlar. Bu şekliyle aynı zamanda merkezi otoritenin kararları dahilinde kendilerine verilen görevleri yerine getirmeleri pek mümkün değildir. Gelir ve görevlerinin merkezi otorite tarafından belirlenmesi gelirgider dengesinin önemnini ortaya çıkartır. Diğer bir deyişle büyükşehir belediyelerinin hizmet yüküne bağlı olarak gelir kalemlerinin de yeterli düzeyde olması gerekmektedir (Karakaya, 2012:78).

Büyükşehir belediyelerinin mali yapıları çeşitli kanunlarla şu şekilde düzenlenmiştir: Büyükşehir belediyelerinin gelirlerine ait düzenleme 1981 yılında çıkarılan 2380 sayılı kanunla düzenlenmiş ve söz konusu kanunla genel bütçe vergi gelirleri tahsilat toplamı üzerinden ilçe belediyelerine verilen paylardan Bakanlar Kurulu tarafindan belirlenecek oranlar içinden (bu payın miktarı \%35 olarak belirlenmiştir) büyükşehir payı olarak ayrılacağı ifade edilmiştir. Ayrıca, büyükşehirler kendi sınırları içinde genel bütçe vergi gelirleri tahsilat toplamı üzerinden $\% 5$ pay almışlardır. Bakanlar Kurulu, \%5 pay oranını iki katına kadar artırmaya veya kanunî haddine indirmeye yetkili kılınmıştır. Bu payın \%75'inin bu tutardan düşülerek doğrudan ilgili belediye hesabına yatırılması, kalan \%25'in ise büyükşehir belediyelerine nüfuslarına göre dağıtılması öngörülmüştür. Hesaplama ve dağıtım işlemlerinin Maliye Bakanlığınca yapılması yönünde bir düzenleme yapılmıştır. Bu pay zaman içinde kimi düşüşler göstermiş olmakla birlikte, 5216 sayılı yasa ile yeniden \%5'e yükseltilmiştir. (Ulusoy ve Akdemir, 2013:324)

2008'de yürürlüğe giren 5779 sayılı İl Özel İdarelerine ve Belediyelere Genel Bütçe Vergi Gelirlerinden Pay Verilmesi Hakkında Kanun'la pay ayrımı genişletilmiş, oranlar ve dağıtım kriterlerinde yeni kriterler gerçekleştirilmiştir. Buna göre; genel bütçe vergi gelirleri (GBVG) tahsilâtı toplamının \%2,50'si büyükşehir ilçe belediyelerine pay olarak ayrılmakta ve bu payın \%30'u büyükşehir payı olarak ayrılmakta, bu paydan kalan miktar nüfus esasına göre büyükşehir ilçe belediyelerine aktarılmaktadır. Büyükşehir belediyeleri belediye sınırları içinde yapılan genel bütçe vergi gelirleri tahsilâtı toplamından $\% 5$ oranında pay almaktadır. Bu payın \%70’i doğrudan büyükşehir belediyesinin hesabına aktarılmakta, kalan \%30'luk kısım ise, büyükşehir belediyeleri arasında nüfus esasına göre dağıtılmaktaydı (Ulusoy ve Akdemir, 2013:325).

6360 sayılı Kanunun getirdiği en önemli düzenlemelerden biri, 5779 sayılı Kanunda yapılan değişikliklerle genel bütçe gelirleri tahsilatından yapılan dağıtımın yeniden düzenlenmesidir.6360 sayılı yasanın getirmiş olduğu yeni düzenleme ile büyükşehir ilçe belediyelerine ayrılan pay7 \%2,50'den \%4,5'e çıkarmıştır. Bu payın dağıtımı \%90'1 nüfusa, \%10’u yüzölçümüne göre yapılacaktır. Büyükşsehir belediyelerinin sınırları içinde toplanan genel bütçe vergi gelirlerinden aldıkları pay oranını \% $\%$ 'den \%6'ya çıkarılmıştır. Özel tüketim vergisi hariç olmak üzere, büyükşehir belediye sınırları içinde yapılan genel bütçe vergi tahsilatı toplamından ayrılan \%6'lık payın, \%60'1 doğrudan büyükşehir belediyesine aktarılmakta, kalan \%40 ise, \%70'i nüfus, \%30'u yüzölçümü esasına göre büyükşsehir belediyelerine transfer edilmektedir. Ayrıca, büyükşehir belediyelerine GBVG'inden aktarılan payda artış olup, bu artışın ancak bir önceki yılın aynı ayında tahakkuk eden payın \%20'sinden fazla olmayacağını; eğer fazla olduğu takdirde, artış oranı \%20'den az olan büyükşehir belediyelerine bu oranı aşmamak üzere dağıtılmasına ilişkin sınırlamalar kaldırılmıştır. Böylece daha fazla vergi toplanan ve kalabalık olan büyükşehir belediyeleri diğer büyükşehirlere göre avantajlı olacaktır (Agun ve Güler, 2018:8-9). 
6360 sayılı Kanun ile birlikte büyükşehir belediyelerinin toplam vergi gelirlerinden büyük payı almaya başladı ve il özel idarelerinin payının azaldı.Büyükşehir belediyelerinin çoğalması ve hizmet sunmakla mükellef olduğu nüfusun artması nedeniyle genel bütçe vergi gelirlerinden aldıkları kişi başına payın düşük bir oranda arttığını; il özel idarelerinin ise sayısının azalması nedeniyle genel bütçe vergi gelirlerinden aldıkları kişi başına payın daha yüksek oranda arttığı belirtilebilir.(Yüksel, 2016:753)

\subsection{Büyükşehir Belediyelerinin Gelirleri}

Büyükşehir belediyelerinin gelirleri: vergi gelirleri, vergi dışı gelirler ile özel yardım ve fon gelirlerinden oluşmaktadır. Vergi gelirleri, genel bütçe vergi gelirleri tahsilatından alınan pay, belediye vergileri ve belediye harçlarından oluşur. Vergi dışı gelirler, harcamalara katılma payları, teşebbüs gelirleri, işletme karları, belediye taşınır ve taşınmaz mal gelirleri, ücretler, ceza gelirleri, borçlanma ve diğer gelirlerden oluşmaktadır (Özer ve Akçakaya, 2015:111-112).

Türkiye'de en son kabul edilen ve şuan yürürlükte olan 6360 say1lı kanunda yerel vergi gelirlerinin belirlenmesi ve tahsili açısından büyükşehir belediyeleri için yeni bir düzenleme getirilmemiştir. Bu nedenle büyükşehir belediyelerinin bütçelerinde kanun öncesi dönemde olduğu gibi ağırlıklı olarak merkezi idareden yapılan transferler ağırlıklı yerini korumaya devam etmiştir. Merkezi yönetimden transferlerin oranı büyükşehir belediyelerinde diğer bütün belediyelerin ortalamasına göre daha yüksektir. Büyükşsehir belediyelerinin genel bütçe vergi gelirlerinden aldıkları payın diğer belediyelere oranla daha ağırlıklı bir paya sahip olması buna neden olarak gösterilebilir (Arıkboğa, 2016:286).

\subsubsection{Genel Bütçe vergi gelirlerinden ayrılan pay}

6360 sayılı kanunun getirdiği diğer bir yenilik de büyükşehir belediyesi sınırlarını il mülki sınırları olarak tanımlamıştır. Büyükşehir belediyesinin sınırlarının il mülki sınırları olması büyükşehir belediyelerinin görev ve sorumluluklarının büyük ölçüde artmıştır. Artan bu görev ve sorumluluklar da büyükşehir belediyelerine genel bütçeden aktarılan paylarda değişiklik yapılması sonucunu beraberinde getirmiştir.

6360 sayılı kanunun 25. maddesi ile 5779 sayılı kanundaki belediyelere aktarılacak pay oranları değiştirilmiştir. Kanuna göre; "Genel bütçe vergi gelirleri tahsilâtı toplamının yüzde 1,50'si büyükşsehir dışındaki belediyelere, yüzde 4,50'si büyükşsehirlerdeki ilçe belediyelerine ve yüzde 0,5'i il özel idarelerine ayrilacağı" ifade edilmiştir.

Büyükşehir belediyelerine ayrılacak pay oranı ise " 4760 sayılı Özel Tüketim Vergisi Kanununa (Ö.T.V.) ekli (I) sayll listede yer alan mallardan tahsil edilen özel tüketim vergisi hariç olmak üzere, büyükşehir belediye sinırları içinde yapılan genel bütçe vergi gelirleri tahsilâtı toplamının yüzde 6'sı ile genel bütçe vergi gelirleri tahsilâtı toplamı üzerinden büyükşehirlerdeki ilçe belediyelerine ayrlan payların yüzde 30'unun büyükşehir belediye payl" olarak belirlenmiştir.6360 sayılı kanunun getirdiği değişiklikleri şu şekilde tasniflemek mümkündür;

Tablo 1. Büyükşehir Belediyesi Kanunu'nun Genel Bütçe Vergi Gelirlerine Getirdiği Mali Değişiklikler

\begin{tabular}{|c|c|}
\hline Büyükşehir Dışındaki Belediyeler & G.B.V.G. nin \%1,50’I \\
\hline Büyükş̧ehir İlçe Belediyelerine & G.B.V.G. nin \%4,50'si \\
\hline Büyükşehir Belediyelerine & $\begin{array}{l}\text { G.B.V.G.nin (4760 sayılı ÖTV. Kanununun 1 sayılı listesindeki } \\
\text { mallar hariç Büyükşehir belediye sınırlarındaki G.B.V.G.'nin) } \\
\% \text { s } 1 \text { + Büyükşehir İlçe Belediyeleri Payının \%30'u }\end{array}$ \\
\hline
\end{tabular}

Kaynak: Yazarlar tarafından hazırlanmıştır.

5779 sayılı Kanun ile 6360 sayılı Kanunun belediyeler için öngördüğü G.B.V.G.'nden ayrılan payları karşılaştırmalı hali aşağıdaki tablo 2 'de görülmektedir; 
Tablo 2. 5779 sayılı Kanun İle 6360 Sayılı Kanunun Karşılaştırılması

\begin{tabular}{|c|c|c|}
\hline & 5779 sayılı Kanun & 6360 sayılı Kanun \\
\hline B.şehir Dışındaki Belediyelere & G.B.V.G.' nin \%2,85'i & G.B.V.G.' nin 1,50'si \\
\hline B.şehir İlçe Belediyelerine & G.B.V.G.' nin \%2,50'si & G.B.V.G.' nin 4.50'si \\
\hline Büyükşehir Belediyelerine & $\begin{array}{c}\text { G.B.V.G. nin (Büyükşehir belediye } \\
\text { sinırlarındaki) \% 5 i + Büyükşehir } \\
\text { İlçe Belediyeleri Payının \%30 u }\end{array}$ & $\begin{array}{c}\text { 4760 sayıll ÖTV. Kanununun 1 sayıll listesindeki mallar } \\
\text { hariçyükşehir belediye sınırlarındaki G.B.V.G.' nin) } \\
\% \text { 6 s1 + Büyükşehir İlçe Bel. Payının \%30 u }\end{array}$ \\
\hline
\end{tabular}

Kaynak: Yazarlar tarafından hazırlanmıştır.

Tablodan anlaşılacağı üzere büyükşehir belediyelerinin sayısının artması sonucunda il belediyelerin GBVG'den aldığ pay $\% 2,85$ den $\% 1,50$ 'ye düşmüştür. Yaklaşık \%50 ye varan bir düşüş olmuştur. 6360 sayılı yasanın yürürlüğe girmesi ile birlikte \% 2,50'lik büyükşehir ilçe belediyeleri payı \% 4.50'ye çıkarılmış böylece \%80 civarında bir artış gerçekleşmiştir. \%5 lik büyükşehir belediye payları da \%6'ya çıkarılmıştır. Yine 6360 sayılı yasa ile yapılan bir diğer değişiklik, \% 6'lık büyükşehir belediye payının yüzde 60'ının doğrudan ilgili büyükşehir belediyesi hesabına, kalan \% 40'lık kısmının \% 70'inin nüfusa, \% 30'unun ise yüzölçümü esasına göre büyükşehir belediyeleri arasında dağıtılmıştır (Gökmen ve Yeşil, 2014:88).

\subsection{Büyükşsehir Belediyesinin Giderleri}

Büyükşehir belediyelerinin giderlerinin önemli bir kısmı, yatırım ve transfer alt kalemlerinden oluşmaktadır. Bunun nedeni ise, büyükşehir belediyelerinin alt yapı yatırımlarının büyük meblağlardan oluşmakta ve belediyelerin bu isteği borçlanma ile finanse etmesidir. Normal belediyelerde yaşanan kaynak sıkıntısı büyükşehirlerde yatırımı sıkıntıya sokmakta ve merkezi idarenin yaptığı mali transferlere bağlı kalmaktadırlar. Oysaki büyükşehir belediyeleri ekonomik faaliyetlerinin önemli bir kısmı kendi bölgelerinde toplandığı için gelir elde etme ve bunları yatırıma dönüştürme olanakları vardır. Bu nedenle de büyükşehir belediyeleri normal belediyelerden daha fazla yatırım yapmaktadırlar. Yapılan uzun vadeli yatırımlar giderlerin önemli bir bölümünü borçlanmayla karşılanmasını gerektirmektedir. $\mathrm{Bu}$ da belediyelerin transfer harcamaları giderlerinin yüksek olmasına neden olmaktadır (Ulusoy ve Akdemir, 2012:320).

Yıllar itibariyle harcamaların ekonomik dağılımına bakıldığında belediye giderleri içerisinde en yüksek pay cari harcamalara aittir. Bu oran 1929-2000 yılları arasında ortalama olarak \%53 civarında ve yatırım harcamalarının oranı, aynı dönemde ise \%30 civarında kalmıştır. Diğer yandan transfer harcamalarının oranı ise yine aynı dönem itibariyle \%17 dolayında seyretmiştir. Özetlersek, bu dönemler için cari harcamaların payı azalırken transfer harcamalarının payınnın arttığı görülmektedir (Bülbül, 2006:94).

Büyükşehir belediyelerinin 2006 yılında analitik bütçe sınıflandırmasına geçmesi nedeniyle büyükşehir belediyelerindeki ekonomik sınıflandırma da değişikliğe uğramıştır. Değişikliğe göre ekonomik sınıflandırma bazında; personel giderleri, sosyal güvenlik kurumlarına personel giderleri, mal ve hizmet alım giderleri, faiz giderleri, cari transferler, sermaye giderleri, sermaye transferleri ve borç verme şeklinde sınıflandırılmaya başlanmıştır (Ulusoy ve Akdemir, 2012:321).

Cari harcamalar içinde en büyük kalemi oluşturan personel harcamalarına ilişkin olarak 5393 sayılı Yasa ile getirilen yeni düzenlemelerden biri de yasanın 49. maddesinde yer alan "Belediyenin yıllık toplam personel giderleri, gerçekleşen en son yıl bütçe gelirlerinin 213 sayılı Vergi Usul Kanununa göre belirlenecek yeniden değerleme katsayısı ile çarpımı sonucu bulunacak miktarın yüzde otuzunu aşamaz. Nüfusu 10.000'in altında olan belediyelerde bu oran yüzde kırk olarak uygulanır", hükmü olmuştur. Yeni personel alımının önüne geçilmesi amacını taşıyan bu madde yine yeni yasada yer alan esnek bir istihdam yöntemi olan geçici işçilik ve şirketler eliyle yeni istihdamlar oluşturulmasının önünü açmıştır. 


\section{ANTALYA BÜYÜKŞEHIR BELEDIYESININ MALİ YAPISI}

\subsection{Antalya Büyükşehir Belediyesi Teşkilatı}

Antalya'da belediye teşkilatı ilk kez Osmanlı devrinde 1868 'de kurulmuştur. Bu belediyenin temel görevleri temizlik ve çevre düzenlemesi, yol yapım ve onarımı, sağlık hizmetleri olarak düzenlenmiştir. Cumhuriyet dönemindeki Antalya Belediyesi günümüzde uygulanan belediyecilik anlayışını kısmen yansıtmıştır. Bu dönemde Antalya Belediyesi temizlik, sağlık, yol, su, kanalizasyon gibi altyapı ve itfaiyecilik hizmetlerini yürütmekteydi. Antalya Belediyesi; 1994 y1lında "Büyükşehir Belediyesi" olmuş ve alt kademe belediyeleri olarak Muratpaşa, Kepez ve Konyaaltı Belediyeleri kurulmuştur. 06.03.2008 tarih ve 5747 sayılı Büyükşehir Belediyesi Sınırları İçerisinde İlçe Kurulmasına ve Bazı kanunların Değiştirilmesi Hakkındaki Kanun ile Antalya Büyükşehir Belediyesi içinde Aksu, Döşemealtı, Kepez, Konyaaltı ve Muratpaşa adında 5 yeni ilçe kurulmuştur. Çıkarılan kanunla birlikte alt kademe belediyeleri çevresinde bulunan Beldibi, Çalkaya, Çığlık, Doyran, Düzlerçamı, Pınarlı, Varsak, Yeşilbayır ve Yurtpınar belediyeleri birleştirilerek ilçe belediyesi statüsüne dönüştürülmüştür.

\subsection{Antalya Büyükșehir Belediyesinin Mali Yapısı}

\subsubsection{Antalya Büyükşehir Belediyesi Gelirleri}

Antalya Büyükşehir Belediyesinin gelirleri, 5216 sayılı Büyükşehir Belediyesi Kanunu, 2464 sayılı Belediye Gelirleri Kanunu ve 5779 sayılı İl Özel İdarelerine ve Belediyelere Genel Bütçe Vergi Gelirlerinden Pay Verilmesi Hakkında Kanun ile ilgili diğer mali mevzuatta düzenlenmiş olup, bu kanunlar çerçevesinde gelir kaynakları şöyle sınıflandırılabilir: vergi gelirleri, teşebbüs ve mülkiyet gelirleri, alınan bağış ve yardımlar, genel bütçe vergi gelirleri payı, kişi ve kurumlardan alınan diğer paylar, diğer gelirler, sermaye gelirleridir. (Antalya Büyükşehir Belediyesi, 2015-2019 Stratejik Planı)

Tablo 3. Antalya 2006-2017 Dönemi Gerçekleşen Gelir Bütçeleri (TL)

\begin{tabular}{|c|c|c|c|c|c|c|c|c|}
\hline YIL & $\begin{array}{c}\text { Vergi } \\
\text { Gelirleri }\end{array}$ & $\begin{array}{c}\text { Mülk ve } \\
\text { Teşebbüs } \\
\text { Gelirleri }\end{array}$ & $\begin{array}{l}\text { Alınan Bağış } \\
\text { ve Yardımlar }\end{array}$ & Diğer Gelirler & $\begin{array}{l}\text { Sermaye } \\
\text { Gelirleri }\end{array}$ & $\begin{array}{c}\text { Alacaklardan } \\
\text { Tahsilat }\end{array}$ & $\begin{array}{c}\text { Red ve } \\
\text { İadeler (-) }\end{array}$ & Toplam \\
\hline 2006 & 118.763 .478 & 0 & 14.302 .432 & 24.925 .884 & 11.077.300 & 0 & 0 & 169.069.094 \\
\hline 2007 & 19.661 .168 & 43.561 .289 & 9.385 .608 & 123.836 .090 & 10.405 .759 & 115.551 & 0 & 206.965 .465 \\
\hline 2008 & 22.648 .553 & 30.509 .966 & 8.642 .294 & 157.907 .607 & 15.878 .783 & 30.809 & 3.719 .725 & 231.898.287 \\
\hline 2009 & 17.328 .478 & 30.738 .209 & 2.435 .213 & 153.306 .696 & 3.860 .616 & 3.034 .809 & 2.957 .741 & 207.746 .280 \\
\hline 2010 & 20.538 .807 & 37.664 .798 & 132.648 & 196.266.794 & 50.428 .377 & 1.981 .571 & 97.743 & 306.915 .252 \\
\hline 2011 & 23.861 .096 & 48.198 .408 & 314.454 & 218.611 .139 & 12.714 .469 & 231.369 & 9.532 .402 & 294.398.533 \\
\hline 2012 & 12.129 .508 & 62.405 .793 & 864.837 & 247.493 .052 & 5.388 .202 & 512.309 & 0 & 328.793.701 \\
\hline 2013 & 13.248 .020 & 81.529 .690 & 0 & 295.065 .108 & 1.281 .230 & 0 & 530.390 & 390.593.659 \\
\hline 2014 & 13.956 .577 & 84.114 .299 & 2.407 .857 & 594.498 .501 & 319.809 & 0 & 0 & 695.297 .043 \\
\hline 2015 & 49.395 .465 & 92.419 .227 & 91.683 .045 & 784.849 .142 & 7.034 .583 & 0 & 0 & 1.025.381.671 \\
\hline 2016 & 47.329 .462 & 112.232 .522 & 35.246 .429 & 862.085 .716 & 38.479 .801 & 0 & 0 & 1.095.373.929 \\
\hline 2017 & 47.415 .175 & 170.831 .724 & 53.245 .830 & 1.013 .549 .588 & 66.327 .243 & 0 & 0 & 1.351 .369 .560 \\
\hline
\end{tabular}

Kaynak: 2006-2017 Yılları Arası Antalya Büyükşehir Belediyesi Faaliyet Raporları

Antalya Büyükşehir Belediyesinin toplam gelirlerine bakıldığında genel olarak artmakta olduğu görülmektedir. Özellikle vergi gelirleri birkaç yıl haricinde bir önceki yıla göre sürekli artarken buna ek olarak diğer gelirler de 
düzenli olarak artmıştır. Fakat alınan bağış ve yardımlar 2006 yılından 2013 yılına kadar sürekli olarak azalmıştır. 2013-2017 yıllarında alacaklardan tahsilat gelirinin olmadığı görülmektedir.

Vergi gelirleri bütçede önem sırasında çoğu yılda üçüncü sırayı almaktadır. 2017 yılında ise vergi gelirleri \%3,51'lik oranla 5. sıraya kadar gerilemiştir .Vergi gelirleri, belediyenin topladığ 1 vergiler, resim ve harçlardan oluşmaktadır. Mali özerkliğin sağlanması açısından vergi gelirlerinin bütçedeki oranının artırılması gerekmektedir. Fakat 2006-2017 yılları arasında vergi gelirleri düzenli bir artış sağlayamamış aksine bir yıl artarken diğer yıl azalma göstermiştir.

Türkiye'de bütçe sisteminin değişmesiyle 2006 yılında bütçe gelirleri sınıflandırma sistematiğinde de yapılan değişiklikten dolayı vergi gelirleri 2006 yılında diğer yıllara göre çok yüksek gözükmektedir. Bunun nedeni, 2006 yılında vergi gelirlerinin içerisinde merkezi bütçeden aktarılan payların da yer almasıdır. 2006 yılından itibaren merkezi bütçeden aktarılan paylar vergi gelirlerinin içinden çıkarılmış ve diğer gelirler kaleminde yer almaya başlamıştır. 2007 yılında tablo 3'de vergi gelirlerinin direkt olarak düştüğü görülmektedir. Fakat daha önce de açıklandığı üzere 2006 yılında vergi gelirlerinin içinde merkezi bütçeden aktarılan paylar da olduğu için bu kadar yüksek görülmektedir. 2007 y1lında bütçe gelirleri sınıflandırması değiştiği için, merkezi bütçeden aktarılan paylar vergi gelirlerinin içerisinden çıkarıldığı için vergi gelirlerinde düşüş görülmektedir.

Mülk ve teşebbüs gelirleri, gelir bütçesinde bir başka önemli gelir kalemidir. Bu gelirler belediyenin öz gelir kaynağıdır. Bu gelirlerin içinde gayrimenkul kiraları ile belediye işletmelerinin payı büyüktür. İncelenen dönem arasındaki yıllarda da zaten düzenli olarak arttı̆̆ görülmektedir.

2006 yılında mülk ve teşebbüs gelirlerinin sıfır olmasının nedeni ise, bütçe sisteminden kaynaklanmaktadır. 2006 yılında uygulanan bütçe sınıflandırmasında böyle bir gelir kalemine yer verilmemiştir ve 2006 da gerçekleşen gelirlerin büyük bir kısmı daha önce belirtildiği gibi vergi gelirlerine ait olarak gerçekleşmiştir.

Bağış ve yardımların gelir bütçesinde çok önemli bir paya sahip olmadığı görülmektedir. Aslında bu değer Tablo 3'te incelediğinde 2006 yılında yüksek bir rakamla başlamış ve 2011 yılına kadar giderek düşmüştür. 2011 ve 2012 yılında bir artış meydana gelmiş bu artış da proje gelirlerinden kaynaklanmıştır. 2013 yılında sıfır olmasının nedeni ise bütçede gelir olarak tahmin edilmesine rağmen hiçbir şekilde gelir sağlanamamış olmasıdır. 2014 yılında kişi ve kurumlardan alınan bağışlar ve proje gelirleri olması nedeniyle tekrar gelir elde edilmiştir. Göze çarpan bir başka nokta ise 2015 yılında bu gelir kaleminden sağlanan gelirin bir önceki yıla göre birden 40 katına yaklaşık bir gelirin sağlanmış olmasıdır. 2015 yılında bütçede tahmin edilmemesine rağmen gerçekleşmesi buna bir neden olarak gösterilebilir. Bu yılda diğer yıllardan farklı olarak merkezi yönetim bütçesinde yer alan idarelerden alınan bağış ve yardımların da gerçekleştiği görülmektedir.

Diğer gelirler, Antalya Büyükşehir Belediyesi'nin gelir bütçesine bakıldığında en önemli gelir kaleminin diğer gelirler olduğu görülmektedir. Çünkü tablo 3 'ten de anlaşıldığı üzere 2006-2017 yıllarında en fazla paya sahip olan gelir türüdür. Bu gelirleri aynı zamanda Genel Bütçe ve Merkezi İdare Vergi gelirlerinden alınan paylar oluşturmaktadır. $\mathrm{Bu}$ da, belediyenin mali olarak merkeze bağlı kaldığını göstermektedir. Diğer gelirler her yıl düzenli olarak artmıştır. Diğer gelirlerin bütçe gelirleri içinde en yüksek paya sahip olduğu yıl \%85,5 ile 2014 y1lidır.

Sermaye gelirlerinin bütçede en fazla olduğu y1l \%16,4 oranıla 2010 yılı olmuştur.

Alacaklardan tahsilat, red ve iadeler ise bütçe içinde önemsiz büyüklüktedir. Alacaklardan tahsilat gelirleri sadece 2007 ve 2012 yılları arasında gelir getirmiş ve 2013 yılından itibaren herhangi bir gelir sağlamayarak bütçede sıfır değerini almıştır. Tablo 1'de red ve iadeler kısmına bakıldığında da 2008-2011 ve 2013 yıllarında gelir bütçesinden eksilmeye yol açtığı görülmektedir.

\subsubsection{Antalya Büyükşehir Belediyesi Giderleri}

Antalya Büyükşehir Belediyesinin giderleri içinde genel olarak mal ve hizmet alımları için yapılan harcamalar, personel harcamaları, sosyal güvenlik harcamamalarının yanı sıra, faiz, transfer ve sermaye giderleri yer almaktadır. Antalya Büyükşehir Belediyesinin 2006-2017 dönemine ait giderleri aşağıda tablo 4’te gösterilmiştir. 
Tablo 4. Antalya Büyükşehir Belediyesi 2006-2017 Dönemi Gider Bütçesi

\begin{tabular}{|l|c|c|c|c|c|c|c|c|}
\hline YIL & $\begin{array}{c}\text { Personel } \\
\text { Giderleri }\end{array}$ & $\begin{array}{c}\text { Sosyal } \\
\text { Güvenlik } \\
\text { Giderleri }\end{array}$ & $\begin{array}{c}\text { Mal ve } \\
\text { Gizmet } \\
\text { Giderleri }\end{array}$ & $\begin{array}{c}\text { Faiz } \\
\text { Giderleri }\end{array}$ & $\begin{array}{c}\text { Cari } \\
\text { Transferler }\end{array}$ & $\begin{array}{c}\text { Sermaye } \\
\text { Giderleri }\end{array}$ & $\begin{array}{c}\text { Yedek } \\
\text { Ödenekler }\end{array}$ & Toplam \\
\hline $\mathbf{2 0 0 6}$ & 38.417 .725 & 5.602 .263 & 41.862 .184 & 17.223 .844 & 9.692 .868 & 64.895 .882 & 3.752 .796 & $\mathbf{1 8 1 . 4 4 7 . 5 6 2}$ \\
\hline $\mathbf{2 0 0 7}$ & 42.713 .572 & 6.267 .628 & 67.387 .857 & 8.711 .090 & 16.525 .845 & 86.493 .122 & 2.245 .412 & $\mathbf{2 3 0 . 3 4 4 . 5 2 6}$ \\
\hline $\mathbf{2 0 0 8}$ & 46.442 .533 & 7.506 .428 & 92.419 .831 & 13.526 .734 & 6.077 .185 & 183.496 .956 & 3.971 .520 & $\mathbf{3 5 3 . 4 4 1 . 1 8 7}$ \\
\hline $\mathbf{2 0 0 9}$ & 51.649 .160 & 8.360 .917 & 111.993 .306 & 28.388 .545 & 5.771 .098 & 221.555 .369 & - & $\mathbf{4 2 7 . 7 1 8 . 3 9 5}$ \\
\hline $\mathbf{2 0 1 0}$ & 57.362 .551 & 10.585 .468 & 117.674 .549 & 24.935 .625 & 7.530 .143 & 45.506 .747 & - & $\mathbf{2 6 3 . 5 9 5 . 0 8 3}$ \\
\hline $\mathbf{2 0 1 1}$ & 65.664 .777 & 12.214 .996 & 154.739 .495 & 32.323 .758 & 14.428 .966 & 51.679 .330 & - & $\mathbf{3 3 3 . 0 0 2 . 6 4 3}$ \\
\hline $\mathbf{2 0 1 2}$ & 80.528 .841 & 12.183 .803 & 212.766 .767 & 28.742 .639 & 8.268 .098 & 64.701 .840 & - & $\mathbf{4 0 7 . 1 9 1 . 9 8 0}$ \\
\hline $\mathbf{2 0 1 3}$ & 84.245 .327 & 13.118 .506 & 214.793 .530 & 30.284 .544 & 24.137 .811 & 55.705 .027 & - & $\mathbf{4 2 3 . 7 7 6 . 6 4 6}$ \\
\hline $\mathbf{2 0 1 4}$ & 128.619 .974 & 21.107 .479 & 475.805 .202 & 32.299 .229 & 25.331 .969 & 53.993 .800 & - & $\mathbf{7 4 5 . 7 2 4 5 6 4}$ \\
\hline $\mathbf{2 0 1 5}$ & 150.526 .850 & 22.925 .972 & 365.396 .715 & 30.870 .539 & 29.768 .776 & 276.223 .508 & - & $\mathbf{8 9 2 . 5 5 7 . 9 1 1}$ \\
\hline $\mathbf{2 0 1 6}$ & 173.122 .814 & 25.072 .337 & 529.634 .506 & 24.072 .370 & 44.050 .407 & 546.456 .768 & & $\mathbf{1 . 3 4 2 . 4 1 4 . 8 0 1}$ \\
\hline $\mathbf{2 0 1 7}$ & 161.989 .818 & 24.174 .870 & 605.135 .021 & 31.821 .828 & 42.864 .349 & 1.070 .356 .573 & & $\mathbf{1 . 9 4 5 . 0 5 6 . 3 4 3}$ \\
\hline
\end{tabular}

Kaynak: 2006-2017 Yılları Arası Antalya Büyükşehir Belediyesi Faaliyet Raporları

Antalya Büyükşehir Belediyesinin gider bütçesine bakıldığında, toplam giderlerinin bir önceki yıla göre 2010 yılı hariç sürekli olarak arttığı görülmektedir. Gider kalemleri içinde en önemli artışı gösteren mal ve hizmet alım giderleri olmuştur.

Personel giderleri, Antalya Büyükşehir Belediyesi'nin gider bütçesinde personel giderleri üçüncü bazı yıllarda 2.sırayı aldığı görülmektedir. Her yıl sürekli artış gösteren personel giderleri gider bütçesinde istikrarlı bir yap1 oluşturmuştur. Bunun nedeni kaynakların etkili ve ekonomik kullanımı açısından ve sağlanan hizmetlerin aksamaması için emekli olan, izne ayrılan personelin yerine, personel alımlarının sınırlı sayıda da olsa yapılması olarak gösterilebilir.

Genel olarak tablodan da görüldüğü üzere, yıllar arası geçişlerde en az artış personel giderlerinde görülmüş, en fazla artış da mal ve hizmet alımlarında görülmüştür. Personel giderlerinin en az artış sağlamasının nedeni, 5393 sayılı Büyükşehir Belediye Kanunu ile personel giderlerinde bir sınırlamaya gidilmiş olması ve personel giderlerinin bütçe giderlerinin \%30'unu geçemeyeceği hükmünün yer almasıdır.

Sosyal güvenlik giderleri, Antalya Büyükşehir Belediyesi'nin gider bütçesinde sosyal güvenlik giderleri önemsenmeyecek kadar azdır. Tablo 4'ten görüldüğü üzere 2013'den 2014 yılına geçiş yapıldığında bu gider kaleminde önemli sayılabilecek bir artış söz konusu olmuştur. Bunun nedeni de 2013 ve 2014 yıllarına ait faaliyet raporlarının incelenmesi sonucu memur ve işçi sayısında bir artış meydana gelmesi ve 2013 yılında geçici personel olmamasına rağmen 2014 yılında geçici personel ${ }^{1}$ alınmasıdır.

1 Geçici Personel: "Bir yıldan az süreli veya mevsimlik hizmet olduğuna devlet personel başkanlığı ve maliye bakanlığının görüşlerine dayanılarak bakanlar kurulunca karar verilen görevlerde ve belirtilen ücret ve adet sınırları içinde sözleşme ile çalıştırılan ve işçi sayılmayan kimselerdir".Bkz.(www.kamupersoneli.net) 
Mal ve hizmet giderleri, genellikle her yıl düzenli olarak artan giderler arasında en önemlisi mal ve hizmet giderleridir. Buradan hareketle 2006-2017 dönemi arasındaki yıllarda tahmin edilen bütçeye göre gerçekleşen bütçede mal ve hizmet giderlerinin gerçekleşme rakamlarına bakıldığında, rakamların genellikle yüksek olduğu görülmektedir. Bu giderlerin düzenli olarak artış gösterdiği görülmektedir. Yani harcamalar içindeki en yüksek pay son 6 yılda mal ve hizmet alımlarına aittir. Mal ve hizmet giderlerinin payının yüksek olmasının nedeni de özelleştirme nedeniyle temizlik, park ve bahçelerin bakımı gibi bazı hizmetlerin özel sektörden alınmaya başlaması olarak gösterilebilir.

Faiz giderleri, faiz giderleri alınan iç ve dış borçların faizlerini göstermesi nedeniyle her zaman bütçede yer verilen bir gider türü olmuştur. Tablo 4'te faiz giderlerinin bir yıl düşüş gösterip bir sonraki yıl artış gösterdiği görülmektedir. Bunun nedeni de bütçe açığının finansmanını sağlamak amacıyla alınan iç ve dış borçlara bağlı olması ve alınan borçların yıllık faiz giderini hesaplayan bir gider kalemidir.

Cari transfer giderleri, Antalya Büyükşehir Belediyesi'nin gider bütçesinde olması gereken temel giderlerden biridir. Cari transferler gider kaleminin altında yer alan alt gider kalemleri görev zararları, kar amacı olmayan idarelere yapılan transferler, hane halkı transferleri, yurtdışına yapılan transferler ve giderlerden ayrılan paylar şeklindedir. Bu gider kalemi bütçeye göre gerçekleşme oranları az olan bir gider türüdür. Fakat Tablo 4'e bakıldığında 2013 yılında gerçekleşen gider rakamının 2012 yılına göre 3 kat artış göstermiştir. Bunun nedeni görev zararlarının 2012 yılına göre 2013 yılında daha fazla olması ve kar amacı gütmeyen kuruluşlara yapılan transferlerin 2013 yılında daha fazla tahmin edildiği ve nerdeyse tamamına yakın bir kısmının da gerçekleşmesidir.

Sermaye giderleri, özellikle göze çarpan bir diğer gider ise sermaye giderleridir. 2006 yılından itibaren dört yıl boyunca artarak devam eden sermaye giderleri 2010 ve 2011 yıllarında ciddi bir düşüş yaşamıştır. Bundan sonraki yıllarda bir artış bir azalış göstererek devam etmiş fakat 2015 yılında yine ciddi bir artış göstermiştir. 2010-2015 yılları arasında bir yıl artış bir yıl azalış gösteren sermaye giderlerine rağmen gider bütçelerinde toplama bakıldığında sürekli artış göstermiştir. Özellikle 2015 yılında başlayan artışta 2015 yılına ait faaliyet raporunda yer alan gider bütçesinin sınıflandırmasına bakıldığında 2014 yılına göre tahmin edilen rakamın daha fazla olması ve yarısından fazlasının gerçekleşmesi göze çarpmaktadır. 2015 yılında ve sonrasında sermaye giderlerinin armasının nedeni, gayrimenkul alımı ve kamulaştırılmasının artması ve gayrimenkul sermaye üretiminin önceki yıllara göre kat kat daha fazla olması olmasıdır.

Yedek ödenekler, gider bütçelerinde yer alan bir başka gider kalemi yedek ödeneklerdir. Yedek ödenek Mahalli İdareler Bütçe ve Muhasebe Yönetmeliği'ne göre; "Bütçede öngörülen hizmet ve amaçları gerçekleştirmek, ödenek yetersizliğini gidermek veya bütçenin düzenlenmesi ve görüşülmesi sırasında düşünülmeyen veya öngörülmeyen ve bütçede tertibi bulunmayan ancak yerine getirilmesi zorunlu hizmetlere ilişkin giderleri karşılamak üzere, gerektiğinde diğer tertiplere aktarma yapmak amacıyla "09-Yedek Ödenek" tertibine" konulan ödenek şeklinde tanımlanabilir (m.38). Yedek ödeneklerin bütçe içerisindeki payı nerdeyse yok denilecek kadar azdır. Sadece 2006, 2007 ve 2008 yıllarında yedek ödenek istenmiş ve bunun dışındaki yıllarda yedek ödenek istemeye ihtiyaç duyulmamıştır. Bütçede yer verilen gider rakamı yetersiz kaldığında ödemesi yapılamayan gider kalemleri için, bir sonraki başlıkta yer alan kesin hesap ve tahmini bütçe karşılaştırmalarında da incelenecek olan borçlanma ve ek bütçe talep edilmesi yoluna gidilmiştir.

\subsubsection{Antalya Büyükşehir Belediyesi Bütçesi}

Antalya Büyükşehir Belediyesinin 2006-2017 dönemine ait bütçe ve kesin hesaplarının karşılaştırmasına bakılarak bütçenin gerçekleşeme yüzdesi hakkında bilgi edinilebilir. 
Tablo 5.1 Antalya Büyükşehir Şehir Belediyesi’nin 2006-2017 Dönemi Bütçe-Kesin Hesaplarının Karşılaştırılması (Bin TL)

\begin{tabular}{|c|c|c|c|c|c|c|}
\hline \multirow{2}{*}{ YIL } & \multicolumn{3}{|c|}{ GELIR } & \multicolumn{3}{|c|}{ GIDER } \\
\hline & BÜTÇE & KESINN HESAP & $\begin{array}{c}\text { GERÇEKLEŞME } \\
\text { YÜZDESİ }\end{array}$ & BÜTÇE & KESİN HESAP & $\begin{array}{c}\text { GERÇEKLEŞME } \\
\text { YÜZDESI }\end{array}$ \\
\hline 2006 & $240.000 .000,00$ & 169.069 .094 .05 & $\% 70,44$ & $256.500 .000,00$ & $181.447 .562,05$ & $\% 70,73$ \\
\hline 2007 & $292.500 .000,00$ & $206.965 .465,68$ & $\% 70,75$ & $371.300 .000,00$ & $230.344 .524,81$ & $\% 62,04$ \\
\hline 2008 & $400.000 .000,00$ & 231.898.287,98 & $\% 57,97$ & $475.000 .000,00$ & $353.441 .186,75$ & $\% 74,41$ \\
\hline 2009 & 420.000 .000 .00 & $207.746 .281,00$ & $\% 49,46$ & $500.000 .000,00$ & $427.718 .395,70$ & $\% 85,54$ \\
\hline 2010 & $400.000 .000,00$ & $306.915 .252,11$ & $\% 77$ & $420.000 .000,00$ & $263.595 .2,55$ & $\% 62.76$ \\
\hline 2011 & $450.000 .000,00$ & $294.398534,04$ & $\% 65,42$ & $500.000 .000,00$ & $333.002 .643,00$ & $\% 66,60$ \\
\hline 2012 & $540.000 .000,00$ & 328.793 .700 .92 & $\% 60,88$ & $620.000 .000,00$ & $407.191 .979,73$ & $\% 65,67$ \\
\hline 2013 & $545.000 .000,00$ & 390.593 .659 .24 & $\% 71,66$ & $650.000 .000,00$ & $423.776 .645,78$ & $\% 65,19$ \\
\hline 2014 & $833.000 .000,00$ & $695.297 .043,13$ & $\% 83,46$ & $903.156 .583,03$ & $745.724 .564,32$ & $\% 82,56$ \\
\hline 2015 & $800.000 .000,00$ & $1.025 .381 .671,44$ & $\% 128$ & $1.086 .669 .553,63$ & $892.557 .910,70$ & $\% 82,13$ \\
\hline 2016 & $1.260 .000 .000,00$ & 1.095.373.928.99 & $\% 86$ & $1.681 .097 .939,62$ & $1.342 .414 .801,14$ & $\% 79,85$ \\
\hline 2017 & $1.850 .000 .000,00$ & $1.351 .369 .560,11$ & $\% 73$ & $2.814 .638 .546,16$ & $1.945 .056 .343,13$ & $\% 69,10$ \\
\hline
\end{tabular}

Kaynak: 2006-2017 Yılları Arası Antalya Büyükşehir Belediyesi Faaliyet Raporları

Antalya Büyükşehir Belediyesinin gelir bütçesine bakıldığında bütçe gerçekleşme yüzdesinin en iyi sağlandığı yıl 2015 ve 2016 yıllarıdır. Hatta 2015 yılında beklenenden daha fazla gelir elde edilmiştir. Bu yılda gelirler içerisinde artışı etkileyen gelirler sermaye gelirleri ve alınan bağış ve yardımların 2014 yılına göre kat kat artış göstermesi olmuştur. Gelirler kısmında sapmanın en fazla olduğu yıl ise, 2009 y1lı olmuştur. Gider bütçesinde ise en iyi tahmin edilen yıl ise \%85,54 ile 2009 yılı olmuştur. Sapmanın en fazla olduğu yıl ise 2007 yılıdır.

Hem gelir bütçesinde hem de gider bütçesinde tahmin edilen ve gerçekleşen gelir ve giderler arasında \%30-40 fark olduğu tablo 5'te görülmektedir. Bu durumda bütçedeki samimiyet ilkesine uyulmadığı söylenebilir. Gelir ve gider arasındaki sürekli oluşan bir açık vardır. $\mathrm{Bu}$ açık hem dış borçlanma hem iç borçlanmayla giderilmektedir. Antalya Büyükşehir Belediyesinin gelir-gider arasındaki dengesizliğin nasıl ortadan kalktığı bir sonraki başlıkta incelenecektir. 


\subsubsection{Antalya Büyükşehir Belediyesinin Bütçe Denkliği ve Borçlanması}

Antalya Büyükşehir Belediyesinin gerçekleşen gelir ve gider tabloları incelendiğinde gelir ve gider arasında bir dengesizlik olduğu görülmektedir.

Tablo 6. Antalya Büyükşehir Belediyesi 2006-2017 Dönemi Bütçe Denkliği ve Borçlanması (Bin TL)

\begin{tabular}{|c|c|c|c|c|c|c|}
\hline YIL & GELİR & GIDER & EK BÜTÇE* & AÇIK (-) & İÇ BORÇ & DIŞ BORÇLANMA \\
\hline 2006 & 240.000 .000 .00 & 256.500 .000 .00 & - & 16.500 .000 & 6.500 .00 & 10.000 .00 \\
\hline 2007 & 292.500 .000 .00 & 371.300 .000 .00 & - & 78.800 .000 & - & 35.440 .400 \\
\hline 2008 & 400.000 .000 .00 & 475.000 .000 .00 & - & 75.000 .000 & 58.000 .00 & 77.265 .00 \\
\hline 2009 & 420.000 .000 .00 & 500.000 .000 .00 & - & 80.000 .000 & 80.000 .000 & \\
\hline 2010 & 400.000 .000 .00 & 420.000 .000 .00 & - & 20.000 .000 & 15.000 .00 & 5.000 .00 \\
\hline 2011 & 450.000 .000 .00 & 500.000 .000 .00 & - & 50.000 .000 & 40.000 .00 & 10.000 .00 \\
\hline 2012 & 540.000 .000 .00 & 600.000 .000 .00 & 20.000 .000 & 80.000 .000 & - & - \\
\hline 2013 & 545.000 .000 .00 & 650.000 .000 .00 & - & 105.000 .000 & - & - \\
\hline 2014 & 833.000 .000 .00 & 903.000 .000 .00 & $156.583,00$ & 70.000 .000 & 31.511 .00 & - \\
\hline 2015 & 800.000 .000 .00 & 875.000 .000 .00 & $83.964 .553,63$ & - & - & - \\
\hline 2016 & $1.260 .000 .000,00$ & $1.460 .000 .000,00$ & $31.713 .291,66$ & $200.000,00$ & - & - \\
\hline 2017 & $1.850 .000 .000,00$ & $2.260 .000 .000,00$ & $355.524 .546,16$ & - & - & $257.471 .271,81$ \\
\hline
\end{tabular}

Kaynak: 2006-2017 Faaliyet Raporlarından Faydalanılarak Oluşturulmuştur

2006 yılındaki gelir gider arasındaki fark 16.500.000,00 TL'dir. Bu miktarın 6.500.000,00 TL'si iç borçlanma şeklinde gerçekleşmiştir. İç Borçlanmanın 500.000,00 YTL'si İller Bankasından kalan kısmı da diğer bankalardan karşılanmıştır. İç borçlanmadan sonra kalan 10.000.000,00 TL'si de dış borçlanma şeklinde gerçekleşmiştir. Dış borçlanmanın tamamı yabancı mali kuruluşlardan karşılanmıştır. Tahmin edilen gelir gerçekleşme oranı ve gerçekleşen oran arasındaki fark bazı gelir tahsilatlarının yapılamamış olmasından kaynaklanmıştır. Tahmin edilen gider gerçekleşme oranı ile gerçekleşen oran arasındaki fark da 2006 yılında yapılması planlanan bazı projelerin 2007 yılında yapımına başlanacak olmasından kaynaklanmışır (Antalya Büyükşehir Belediyesi 2016 Y1l Faaliyet Raporu, 2006:62).

2007 yılındaki gelir-gider dengesizliği, 78.800.000,00 TL olmuştur. Bu miktarın hepsi dış borçlanma ile yabancı bankalardan karşılanmıştır. Fakat borçlanma miktarı 35.440.400 TL olarak gerçekleşmiştir. Bu yılda tahmin edilen gelir ile gerçekleşen oran arasındaki fark, 5281 sayılı Vergi Kanunundaki artışın beklenenin altında gerçekleşmesi ve 5216 sayılı Büyükşehir Belediye Kanununda yer alan gelir kalemlerinin artırılacağ 1 düşünülmüş olmasından kaynaklanmıştır. Tahmin edilen gider gerçekleşme oranı ile gerçekleşen oran arasındaki fark 2007 yılında yapılması düşünülen bazı projelerin 2008 yılında yapımına başlanacak olmasından kaynaklanmıştır (Antalya Büyükşehir Belediyesi 2007 Yılı Faaliyet Raporu, 2007:71).

2008 yılındaki gelir-gider dengesizliği 75.000.000.00 TL'dir. 2008 yılında açığın finansmanı dış borçlanma şeklinde yabancı bankalardan karşılanmıştır. Fakat 2008 yılında göze çarpan olay borçlanmanın Türk Lirası cinsinden değil de EURO şeklinde gerçekleşmiş olmasıdır. Yani 39.000.000 EURO dış borçlanma yapılmıştır. Bunun da 2008 yılında Türk Lirası cinsinden karşılığı 77.265.000,00 TL şeklindedir. Bankalardan alınan iç borçlanma da 58.000.000,00 TL'dir. Toplam borçlanılan miktar tahmin edilenden daha fazla gerçekleşmiş olup 135.265.400,00 TL olmuştur. 2008 yılında tahmin edilen gelir ile gerçekleşen oran arasındaki fark, 5281 sayılı Vergi Kanunundaki artışın beklenenin altında gerçekleşmesi ve 5216 Sayılı Büyükşehir Belediye Kanununda yer alan gelir kalemlerinin artırılacağı düşünülmüş olmasından kaynaklanmıştır. Tahmin edilen gider

\footnotetext{
* Tablo-4 'deki veriler, y1l sonu net ödenektir.
} 
gerçekleşme oranı ile gerçekleşen oran arasındaki fark 2008 yılında yapılması düşünülen bazı projelerin 2009 yılında yapımına başlanacak olmasından kaynaklanmıştır (Antalya Büyükşehir Belediyesi 2008 Faaliyet Raporu, 2008:74-75).

2009 yılında gelir-gider arasındaki fark 80.000.000,00 TL'dir. Bu açığın finansmanı da borçlanma yolu ile giderilmiştir. Tahmin edilen gelir ile gerçekleşen oran arasındaki fark, 5281 Sayılı Vergi Kanunundaki artışın beklenenin altında gerçekleşmesi ve 5216 Sayılı Büyükşehir Belediye Kanununda yer alan gelir kalemlerinin artırılacağı düşünülmüş olmasından kaynaklanmıştır. Tahmin edilen gider gerçekleşme oranı ile gerçekleşen oran arasındaki fark 2009 yılında yapılması düşünülen bazı projelerin 2010 yılında yapımına başlanacak olmasından dolayıdır (Antalya Büyükşehir Belediyesi 2009 Y11ı Faaliyet Raporu, 2009:66).

2010 yılındaki gelir gider farkı da 20.000.000,00 TL açık olarak gerçekleşmiştir. Bu dengesizliğin finansmanı 15.000.000,00 TL iç borçlanma, 5.000.000,00 TL diş borçlanma şeklinde giderilmiş̧ir. 2010 yılı gelir bütçesi gerçekleşme oran $\% 77$ olup tahmin edilen gelir bütçesi ile gerçekleşen gelir bütçesi arasındaki fark, bütçede yer alana bazı gelir kalemlerinin tahsilâtının yapılamamasından kaynaklanmıştır. 2010 yılı gider bütçesi gerçekleşme oran $\% 63$ olup tahmin edilen gider bütçesi ile gerçekleşen gider bütçesi arasındaki fark, yıl içinde yapılması düşünülen bazı yatırımlar ve gider kalemlerinde nakit yetersizliği nedeniyle gerçekleştirilememesinden kaynaklanmıştır (Antalya Büyükşehir Belediyesi 2010 Yılı Faaliyet Raporu, 2010:91-92).

2011 yılında gelir-gider arasındaki dengesizlik 50.000.000,00 TL'dir. Bu açığın finansmanında, 40.000.000,00 TL'si iç borçlanma, 10.000.000,00 TL'si dış borçlanma şeklinde gerçekleşmiştir. Bu şekilde belirtilen borçlanma 5080.000.000.000.000,00 TL olarak gerçekleşmiştir. 2011 yılı harcamaları yapılırken performans esaslı bütçeleme esas alınıp belediye vizyonu ve misyonu çerçevesinde kaynaklar etkin kullanılmıştır. 2011 yılı personel giderleri 65.664.777,16 TL, Mal ve Hizmet Alımları 154.739.495,01 TL olmuştur. Antalya Büyükşehir Belediyesi'nin 2011 yılı bütçesi 500.000.000,00 TL olup, bütçe gerçekleşmesi 333.002.643,00 TL'dir. Yatırımlar, mal ve hizmet alımlarına ayrılan pay \%69,40'dır (Antalya Büyükşehir Belediyesi 2011 Yılı Faaliyet Raporu, 2011:92-93).

2012 yılında bütçe dengesizliği 80.000.000,00 TL olarak gerçekleşmiştir. 2012 yılı gelir bütçesi 540.000.000,00 TL olarak kabul edilmiş olup, buna karşl1ık yıl içerisinde 328.793.700,92TL gelir elde edilmiştir. 2012 y1l gider bütçesi meclis tarafindan 600.000.000,00 TL olarak kabul edilmiş, 20.000.000,00 TL ek bütçe çıkarılarak gider bütçesi 620.000.000,00 TL olarak kabul edilmiş ve ödeneklerden 407.191.979,73 TL harcama yapılmıştır. Kullanılmayan 212.808.020,27 TL ödenek iptal edilmiştir (Antalya Büyükşehir Belediyesi 2012 Yılı Faaliyet Raporu, 2012:60).

2013 yılındaki bütçedeki gelir-gider dengesizliği 105.000.000,00 TL'dir. 2013 yılı gelir bütçesi 545.000.000,00 TL olarak kabul edilmiş olup, buna karşılık y1l içerisinde 390.593.659,24 TL gelir elde edilmiştir (Antalya Büyükşehir Belediyesi 2012 Y1lı Faaliyet Raporu, 2012:55).

2014 yılındaki gelir-gider dengesizliği 70.000.000,00 TL'dir. 2014 y1lı gelir bütçesi 833.000.000,00 TL olarak kabul edilmiş, y1l içerisinde 695.297.043,13 TL gelir elde edilmiştir. 2014 yılı gider bütçesi 903.000.000,00 TL olarak kabul edilmiş, ek olağan üstü ödenek ile toplam 903.156.583,03 TL ödenek toplamına karş1lk 745.724.564,32 TL y1l içerisinde harcanmış 127.705.000,00 TL devam eden projeler için bir sonraki yıla devretmiş 29.727.018,71 TL ödenek iptal edilmiştir (Antalya Büyükşehir Belediyesi 2014 Yılı Faaliyet Raporu, 2014:62).

2015 gelir bütçesi 800.000.000 TL olup bütçeye göre gerçekleşme oran1 \%128 ile 1.025.381.671 TL'dir. 2015 yılındaki bütçe dengesizliği 75.000.000,00 TL şeklinde gerçekleşmiştir. Tahsilatın ve bütçeye göre gerçekleşme oran1 \%129'dur. 2014 tahsilatı 697.766.025 TL, 2015 tahsilat1 1.034.579.963 TL'dir, bu duruma göre 2014 yılına göre 2015 yılında tahsilat oranı \%48, 27 artmıştır. 2015 y1lı gelir bütçesi 1.034.579.963 TL tahsilat yapılmışken bu tahsilattan -9.198.291 TL iade yapılmıştır. İadelerin içinde;

- ASAT Genel Müdürlüğü tarafından 2009 yılı faaliyet gelir gider farkı olarak sehven Büyükşehir Belediyesi hesaplarına yatırılmasından kaynaklanan 4.750.000 TL iade,

- 190.700 TL otopark gelirlerinden,

- 904.634 TL Muayene denetim kontrol ücretinden,

- 501.660 TL Çevre ve Esenlik Gelirlerinden gibi, 
- 2.266.104 TL iade kazı tahrip bedellerinden kaynaklanan iadeler ile taksitlendirme iptallerinden kaynaklanan diğer iadeler ödendikten sonra yılsonu tahsilat toplamı 1.025.381.671 TL'ye ulaşmıştır.

2015 mali y1lı bütçe ödenek toplamının 1.086.669.553 TL olduğu kesinleşen bütçe giderinin ise, 892.557.910 TL olarak tespit edildiği görülmüştür. Bu da bütçenin \%82.10'unu karşılamaktır. Büyükşehir belediyesi 2015 yılının bütçesinin personel giderleri olarak 173.735.660 TL ödeneğin \%19,43 karşılı̆̆ 173.452 .820 TL harcanmıştır. Mal ve hizmet alımı giderleri için toplam 421.453.402 TL ödenek ayrılmış olup, yılsonu itibariyle 365.396.716 TL harcama yapılmıştır. Bütçe giderine oranı \%40,94'tür. 2015 yılında 46.000.000 TL ödenekten 30.870 .538 TL faiz gideri ödemesi yapılmış ve 2015 yılında borçlanma yapılmamıştır. 2015 yılı cari bütçesinden ödenekli gider olarak bulunmayıp geçmiş yıllar ödenmesi gereken borç tutarından bütçe emanetinde olan 205.350.639 TL nakit ödeme ile birlikte toplam 1.097.908.549 TL ödeme gerçekleşmiştir. Sermaye gelirlerinde 2015 yılı itibariyle bir sıçrama görülmüştür. Sıçramanın nedeni sermaye gelirleri içerisinde yer alan taşınmaz satış gelirlerindeki artışından meydana gelmektedir (Antalya Büyükşehir Belediyesi 2015 Denetim Komisyon Raporu, 2015:2-9).

Belediyenin 2016 yılı gelir bütçesine bakıldığında net tahsilatının özellikle kişi ve kurumlardan alınan paylar (826.872.045,57 TL) diğer gelirler kapsamındaki tahsilatlardan elde edildiği görülmektedir. Diğer önemli tahsilatlar ise sirasıyla teşebbüs ve mülkiyet gelirleri (112.232.521,91 TL), kira gelirleri (66.427.140,26 TL), vergi gelirleri (47.329.461,62 TL), mal ve hizmet satış gelirleri (40.880.042,55 TL), sermaye gelirleri (38.479.800,53 TL) ve taşınmaz satış gelirleridir (38.442.865,20 TL). Bütçe gideri toplamına bakıldığında ise, bütçe gideri toplamının özellikle sermaye giderleri $(546.456 .767,71 \mathrm{TL})$ ile mal ve hizmet alım giderlerinde (529.634.505,69 TL) ortaya çıktığ1 görülür. Diğer taraftan gayrimenkul sermaye üretim giderleri (427.545.236,92 TL), hizmet alımları (356.772.713,20 TL) ile personel giderlerinin (173.122.814,26 TL) önemli bir oran teşkil ettiği görülür. 2016 yılında bütçe ile tahmin edilen gelir tutarın 1.260 milyar TL ve net tahsilatın ise 1.095.373.928,99 TL olduğu görülmektedir. Antalya Büyükşehir Belediyesinin 2016 y1lı itibariyle net bütçe ödeneği toplamı 1.681.097.939,62 TL iken bütçe gideri toplamının 1.342.414.801,14 TL, iptal edilen ödeneğin ise 139.569.138,48 TL olduğu görülür. Dolayısıyla bütçe giderlerinde gerçekleşme oranı $\% 79,85$ dolayındadır. 2016 yıl1 gider bütçesi 1.460.000.000,00 TL, devreden ödenek 189.384.648,15 TL, ek olağan üstü ödenek 31.713.291,66 TL ile y1lsonu 1.681.097.939,62 TL net ödenek toplamına ulaşılmıştır. Bu ödeneğin 1.342.414.801,14 TL'si y1l içinde harcanmış, 199.114.000,00 TL devam eden projeler için bir sonraki y1la devretmiş, 139.569.138,48 TL ödenek ise yılsonunda iptal edilmiştir (Antalya Büyükşehir Belediyesi 2016 Y1lı Faaliyet Raporu, 2016).

2017 y1lı gelir bütçesi 1.850.000.000,00 TL olarak tahmin edilmiş bütçeye göre gerçekleşme oranı \% 73,04 'tür. Kesinleşen bütçe ise 1.351.369.560,11 TL olmuştur. 2017 yılında 2016'ya göre gelir bütçesinde \%23'lük bir artış gerçekleşmiştir. 2017 mali yılı bütçe ile verilen 2.260.000.000,00 TL, 2016 y1lından 2017 yılına devam eden projeler için 199.114.000,00 TL ve yıl içerisnde ek olağanüstü 2.814.638.546,16 TL olduğu kesinleşen bütçe giderinin ise, 1.945.056.343,13 TL olarak tespit edilmiştir. 2017 y1lında 31.821.828,04 TL faiz gideri ödemesi yapılmıştır. 257.471.271,81 TL borçlanma yapılmıştır. 2017 yılı harcama ayrıntısına bakıldığında film festivali, piyano festivali, Yörük festivali ve diğer festivallere harcanan miktarın yüksek olduğu görülmüştür (Antalya Büyükşehir Belediyesi 2017 Yı1ı Denetim Komisyonu Raporu, 2017:2-5).

\section{SONUÇ}

Dünyada 1950'lerde yaşanan hızlı kentleşme sonucunda büyük kentlerin daha çok büyümesi belediye sınırlarının dışında düzensiz ve plansız gelişmeler gösterince, anakentlerin yönetiminde özel model arayışı gündeme gelmiştir. Dünyadaki uygulamalarda olduğu gibi ülkemizde de büyükşehir ölçeğindeki belediyeler için normal belediyelerden farklı bir yönetim sistemi benimsenmiştir. Türkiye'de 1984 yılında çıkarılan 3030 sayılı ilk yasa ile yasal statü kazanan büyükşehir belediyeleri bu tarihten itibaren aksaklıkların giderilmeye çalış1lması, yeni düzenlemelerin yapılması gibi faaliyetler sonucunda 2004 yılında güncelleştirilmiş bir yasa ile faaliyetlerine devam etmiştir. 2004 yılında hazırlanan 5216 sayılı yeni yasa kapsamında büyükşehir belediyelerinin yeni uygulamaları 2008 yılında çıkarılan yeni bir yasa ile değiştirilmiştir. Son olarak 2012 yılında 6360 Sayılı Yasa ile büyükşehir belediyelerine dair yeni bir yasa çıkarılmıştır. Bu yasa kapsamında en önemli değişikliklerden bazıları büyükşehir belediyelerinin kapsamlarının genişletilmesi ve yetkilerinin arttırılması olsa da en önemli değişikliklerden biri belediyelerin ekonomik anlamda da daha fazla imkâna sahip olmalarının sağlanmasıdır. 6360 sayılı Kanun, dolaylı da olsa, büyükşehir belediyelerinin vergi gelirlerini artırıcı yöndedir. Büyükşehir sınırlarında yer alan köylerde yaşayanlar da Emlak Vergisi mükellefi olmuş ve $\% 100$ artırmalı vergi ödeyeceklerdir. Çevre Temizlik Vergisi'nde de köylerde yaşayanlar \%25 artırımlı vergi 
ödeyeceklerdir. Bu uygulama beş yıllığına ertelenmiş olup, uzun vadede büyükşehir ve ilçe belediyelerinin öz gelirlerini artırmaya yönelik bir düzenlemedir.

Antalya Büyükşehir Belediyesinin gelirleri genel olarak artmaktadır. Gelir bütçesi içindeki en önemli gelir kaleminin diğer gelirler kalemi olduğu ve bu kalemi de "Genel Bütçe Ve Merkezi İdare Vergi Gelirlerinden Ayrılan Paylar"ın oluşturduğu düşünüldüğünde belediyenin mali olarak merkeze bağımlı kaldığı sonucuna ulaşılmaktadır. Mali özerkliğin sağlanması için öz gelirlerden olan vergi gelirlerinin oranının arttırılması gerekmektedir. Ancak bu durum merkezi yönetim tarafindan çıkarılacak yasalarla düzelebilecektir. Bilindiği üzere öz gelirler, temelde belediyenin kendi sınırlarından topladığı vergiler, resim ve harçlardan oluşmaktadır. Büyükşehir belediyelerine tahsis edilen öz vergi gelirleri büyükşehir yasasından dolayı yetersizdir. Dolayısıyla Antalya Büyükşehir Belediyesinin de öz vergi gelirleri diğer büyükşehir belediyelerinde olduğu üzere yetersiz kalmaktadır. Örneğin büyükşehir belediyelerinin emlak vergisi toplama yetkileri olmadığından, çevre temizlik vergisinden yeterli pay almadıklarından öz vergi gelirleri de yetersiz gözükmektedir. Öz gelirler kapsamında büyükşehir belediyelerinin kendi bölgesinden vergi kaynaklarını vergilendirebilir olması önemlidir. Örneğin; Antalya'nın turizmin başkenti olması ve birçok otelin bulunmasından dolayı bir konaklama vergisinin getirilmesi öz gelirlerinin artırılmasına katkı sağlayacaktır. Ayrıca Antalya ile ilgili yapılan araştırmalar sonucunda Antalya'da bulunan işletmelerinin merkezlerinin başka şehirlerde olmasından dolayı genel bütçe vergi gelirlerinden aktarılan \%6 paydan yeterli düzeyde yararlanmamasına neden olmaktadır (Antalya Büyükşehir Belediyesi Faaliyet Raporu, 2017:135). Diğer bir deyişle bu durum Antalya Büyükşehir Belediyesinin hizmet maliyetlerini arttırırken merkezi bütçeden aldığı vergi payının göreceli olarak düşük kalmasına neden olmaktadır. Antalya büyükşehir belediyesinin gelirleriyle ilgili diğer bir durum da vergi gelirleri ve diğer gelirler düzenli olarak artarken alınan bağış ve yardımlar ve sermaye gelirlerinde ise düzensiz bir seyir gözlenmektedir. Mülk ve teşebbüs gelirleri gelir bütçesinde bir başka önemli kalemdir. İncelenen dönem arasındaki yıllarda düzenli olarak arttığı görülmektedir. Alacak tahsilatları ve iadeler ise bütçe içinde önemsiz büyüklüktedir. Bağlı ilçelerce toplanan emlak vergisi büyükşehir payının da kaldırılması vergi gelirlerini azaltan faktörlerdendir.

6360 sayılı Kanun ile yerel yönetimlere genel bütçeden aktarılan paylarda yaklaşık \%10,5'lik bir artış vardır (http://www.mevzaut.gov.tr).

Gider bütçesinde 6360 sayılı Kanunun uygulanmaya başlamasından sonra giderler düzenli olarak artmaya başlamıştır. Personel giderleri, mal ve hizmet alım giderleri, cari transferler, sermaye giderleri ve sosyal güvenlik kurumu devlet priminin gerçekleşme oranı 2013 yılında artış görülmekle birlikte 2014 y1lından itibaren azaldığ 1 gözlemlenmektedir. 2006-2011 yılları arasındaki giderlerinin gelişimi incelendiğinde 2010 ve 2011 yıllarında personel giderlerinin payının arttığı, bu yıllarda sermaye giderlerinin azaldığı görülmektedir. Bütçe içindeki en yüksek payı yaklaşık \% 40 'lık bir oranla mal ve hizmet alımları kalemi oluşturmaktadır. Bunun temel nedeni özelleştirme nedeniyle temizlik, park ve bahçelerin bakımı gibi bazı hizmetlerin özel sektörden alınmaya başlamasıdır. 2014 seçimlerinden sonra hem gider hem de gelir bütçelerinde artış gözlenmiştir. 2014 seçim sonrası bütçe ve kesin hesaplar karşılaştırıldığında önemli sapmalar görülmektedir. Ayrıca harcamalarındaki artışı biraz daha dengede tutmak için de Antalya Uluslararası film festivali, piyano festivali gibi festivallerini ve eğlencelerini daha düşük maliyetle karşılayabilirler. Antalya, 2015 yılında G20 zirvesi ve 2016 yılında EXPO gibi dünya çapındaki organizasyonlara ev sahipliği yaptığı için giderleri artmıştır. Bu yıllarda personel alımı artmış ve 2017 yılı itibari ile bu sayı düşmüştür. Diğer bir gider kalemi olan hizmet alımlarında da artış olmuştur (Antalya Büyükşehir Belediyesi Faaliyet Raporu, 2017:135).

Gelir ve giderler arasında çok fazla açık bulunmayan Antalya Büyükşehir Belediyesinde bütçe açığının finansmanı makul derecede yapılan borçlanmalarla karşılanmıştır.

Son olarak Antalya Büyükşehir Belediyesi mali yapısı yıllar itibariyle incelendiğinde tahmin edinilen bütçeden önemli sapmalar olduğu ve borçlanmaya başvurdıkları görülmektedir. Antalya Il'inin coğrafi yapısı ile ilgili özel durumlar hizmet sunum maliyetini arttırmaktadır. Kıyı şeridine yerleşik olan Antalya İl'inin doğusu ile batısı arasındaki mesafenin 600 kilometreyi bulması ilave kaynak ihtiyacı doğurmaktadır. 


\section{KAYNAKÇA}

AGUN, Bilge Hakan ve GÜLER, Mahmut (2017), "Büyükşehir Belediyelerinin Gelir Yapılarının Değerlendirilmesi: 2006-2015", Yüzüncü Yıl Üniversitesi Sosyal Bilimler Enstitüsü Dergisi, S.1(Özel Say1 4), http://www.yyusbedergisi.com/dergi/buyuksehir-belediyelerinin-gelir-yapilarinindegerlendirilmesi-2006-201520180101043601.pdf (Erişim Tarihi: 17.12.2018).

ANTALYA BÜYÜKŞEHIR BELEDIYYE BAŞKANLIĞI (2007), 2006 Yılı Faaliyet Raporu, Antalya Büyükşsehir Belediye Başkanlığı Yayını, Antalya.

ANTALYA BÜYÜKŞEHİR BELEDIYYE BAŞKANLIĞI (2008), 2007 Yılı Faaliyet Raporu, Antalya Büyükşsehir Belediyesi Yayını, Antalya.

ANTALYA BÜYÜKŞEHİR BELEDİYE BAŞKANLIĞI (2009), 2008 Yılı Faaliyet Raporu, Antalya Büyükşehir Belediyesi Yayını, Antalya.

ANTALYA BÜYÜKŞEHİR BELEDIYE BAŞKANLIĞI (2010), 2009 Yılı Faaliyet Raporu, Antalya Büyükşehir Belediyesi Yayını, Antalya.

ANTALYA BÜYÜKŞEHIR BELEDIYE BAŞKANLIĞI (2011), 2010 Yılı Faaliyet Raporu, Antalya Büyükşehir Belediyesi Yayını, Antalya.

ANTALYA BÜYÜKŞEHİR BELEDIYE BAŞKANLIĞI (2012), 2011 Yılı Faaliyet Raporu, Antalya Büyükşehir Belediyesi Yayını, Antalya.

ANTALYA BÜYÜKŞEHIR BELEDİYE BAŞKANLIĞI (2013), 2012 Yılı Faaliyet Raporu, Antalya Büyükşehir Belediyesi Yayını, Antalya.

ANTALYA BÜYÜKŞEHİR BELEDIYE BAŞKANLIĞI (2014), 2013 Yılı Faaliyet Raporu, Antalya Büyükşsehir Belediyesi Yayını, Antalya.

ANTALYA BÜYÜKŞEHIR BELEDİY BAŞKANLIĞI (2015), 2014 Yılı Faaliyet Raporu, Antalya Büyükşehir Belediyesi Yayını, Antalya.

ANTALYA BÜYÜKŞEHİR BELEDIYE BAŞKANLIĞI (2016), 2015 Yılı Denetim Komisyon Raporu, Antalya Büyükşehir Belediyesi Yayını, Antalya.

ANTALYA BÜYÜKŞEHİR BELEDIYE BAŞKANLIĞI (2016), 2015 Yılı Faaliyet Raporu, Antalya Büyükşehir Belediyesi Yayını, Antalya.

ANTALYA BÜYÜKŞEHİR BELEDIYE BAŞKANLIĞI (2017), 2016 Yılı Faaliyet Raporu, Antalya Büyükşsehir Belediyesi Yayını, Antalya.

ANTALYA BÜYÜKŞEHİR BELEDIYE BAŞKANLIĞI (2017), 2017 Yılı Denetim Komisyonu Raporu, Antalya Büyükşehir Belediyesi Yayını, Antalya.

ANTALYA BÜYÜKŞEHİR BELEDIYE BAŞKANLIĞI (2018), 2017 Yılı Faaliyet Raporu, Antalya Büyükşsehir Belediyesi Yayını, Antalya.

ARIKBOĞA, Ülkü (2015), "Türkiye'de Büyükşehir Belediyesi Transfer Sistemi ve 6360 Sayll Kanunun Etkileri", Marmara Üniversitesi İïB Dergisi, S.37(2), ss.1-30.

ARIKBOĞA, Ülkü (2016), "Türkiye'de Belediyelerin Gelir Yapısl: Sorunlar ve Çözüm Öneriler", Mustafa Kemal Üniversitesi Sosyal Bilimler Enstitüsü Dergisi, S.13(33), ss.276-297.

AZAKLI, Sedat ve ÖZGÜR, Hüseyin (2005), "Belediye Organları ve Organlar Arası İlişkiler: Başkan, Meclis ve Encümen", Yerel Yönetimler Üzerine Güncel Yazllar-1: Reform (Ed. Hüseyin Özgür ve Muhammet Kösecik), Nobel Yayınları, Ankara, ss.297-319.

BÜLBÜL, Duran (2006); Yerel Yönetimler Maliyesi, Gazi Kitabevi, Ankara.

GÖKMEN, Ahmet ve YEŞIL, Ekrem (2011), "Büyükşehir Belediye Sinırları İçinde Tahsil Edilen Genel Bütçe Vergi Gelirlerinden Büyükşehir Belediyelerine Aktarılan Paylar", Denetişim Dergisi, S.8, ss.85-92.

KARAKAYA, Sedat (2012), "Büyükşsehir Belediyelerinin Yapısı ve Yeniden Düzenlenmesi", Yayınlanmamış Yüksek Lisans Tezi, Mustafa Kemal Üniversitesi Sosyal Bilimler Enstitüsü, Hatay. 
MURATOĞLU, Tahir (2015), "Mahalli İdareler Mevzuatında 6360 Sayılı Kanunla Yapılan Değişiklikler", Dicle Üniversitesi Hukuk Fakültesi Dergisi, S.20(32), ss.59-96.

OKTAY ,Tarkan (2016), "6360 Sayll Kanuna Dayalı Büyükşehir Belediye Reformunu Anlama ve Anlamlandırma", Siyasal Bilgiler Fakültesi Dergisi, S.1(1), ss.71-131.

ÖNER, Şerif (2006), Yeni Mevzuat Çerçevesinde Türkiye'de Belediye Yönetimi, Nobel Yayın Dağıtım, Ankara.

ÖZÇELİK, Yusuf (2014), "Büyükşehir Belediyesi İle İlçe Belediyeleri Arasindaki İliş̧kiler", TAAD, S.5(19), ss.117-142.

ÖZER, Mehmet Akif ve AKÇAKAYA, Murat (2014), Yerel Yönetimler: Teorik Boyut, Gazi Kitabevi, Ankara.

PARLAK, Bekir (2015), "Türkiye'de Değissen ve Dönüssen Büyükşsehir Belediyesi: 5216 Sayll Kanundan 6360 Sayılı Kanuna Büyük Dönüşümün Analizi", İdari ve Mali Açıdan Türkiye'de Yerel Yönetimler (Ed. Mehmet Mecek, Mesut Doğan, Bekir Parlak), Bekad Yayınları, Antalya.

TORTOP, Nuri, AYKAÇ, Burhan, YAYMAN, Hüseyin ve ÖZER, Mehmet Akif (2014), Mahalli İdareler, Nobel Yayınları, Ankara.

ULUSOY, Ahmet ve AKDEMIR, Tekin (2012), Mahalli İdareler, Seçkin Kitabevi, Ankara.

YÜKSEl,Cihan (2016), “Yerel Yönetimlerde Kaynak Paylaşim Sistemleri Ve 6360 Sayili Kanun'la Türkiye'deki Değişimler”,Ankara Üniversitesi SBF Dergisi, Cilt:71,No:3,ss731-756.

3030 Sayılı Büyükşehir Belediyelerinin Yönetimi Hakkında KHK'nin Değiştirilerek Kabulü Hakkında Kanun (09.07.1984 tarih ve 18453 sayıl1 Resmi Gazete).

5216 Sayılı Büyükşehir Belediyesi Kanunu (23.07.2004 tarih ve 25531 sayılı Resmi Gazete).

5779 Sayılı İl Özel İdarelerine ve Belediyelere Genel Bütçe Vergi Gelirlerinden Pay Verilmesi Hakkında Kanun (15.07.2008 tarih ve 26937 say1lı Resmi Gazete).

6360 Sayılı On Dört İlde Büyükşehir Belediyesi ve Yirmi Yedi İlçe Kurulması İle Bazı Kanun ve Kanun Hükmünde Kararnamelerde Değişiklik Yapılmasına Dair Kanun (06.12.2012 tarih ve 28489 sayılı Resmi Gazete). 